\title{
METASTAZAVUSIOS MELANOMOS GYDYMAS BRAF INHIBITORIAIS KLAIPE்DOS UNIVERSITETINĖJE LIGONINĖJE. NEPAGEIDAUJAMI REIŠKINIAI
}

\author{
Alvydas Česas ${ }^{1}$, Asta Poškienè ${ }^{1}$ Jolanta Česiene் ${ }^{2}$ \\ ${ }^{1}$ Klaipédos universitetinès ligoninès Onkologijos chemoterapijos klinika, ${ }^{2}$ Klaipédos universitetinès \\ ligoninés Infekciniu ligu departamentas
}

Raktažodžiai: melanoma, BRAF geno mutacija, BRAF ir MEK inhibitorius, nepageidaujamas reiškinys.

\begin{abstract}
Santrauka
Melanoma - piktybinis odos navikas, kilęs iš melanocitų, melaniną produkuojančių ląstelių. Piktybinés melanomos vystymesi labiausiai žinomi du pagrindiniai RAS/RAF/MEK/ERK (MAPK) ir PI3K/ PTEN/AKT (AKT) signalo perdavimo keliai, kurie nenutrūkstamai aktyvuojami įvykus ląstelių genetiniams pokyčiams. Dèl to sutrinka normali ląstelių proliferacija, diferencijacija, angiogenezé, vystosi melanoma. Siekiant surasti geriausią melanomos gydymo būdą, būtina suprasti melanomos biologiją, signalo perdavimo mechanizmus. Aktyvuojančios BRAF geno mutacijos ir intraląstelinių signalo kelių, reguliuojančių ląstelès augimo, dauginimosi, mirties mechanizmus, atradimas pakeitè melanomos biologijos suvokimą ir atvėè plačias galimybės ieškoti taikinių terapijos prieš BRAF bei kitus onkogenus. Klaipèdos universitetinèje ligoninejje 2012-2014 m. pacientai, sergantys metastazavusia melanoma, buvo gydyti BRAF inhibitoriu vemurafenibu, o nuo $2013 \mathrm{~m}$. vykdyta išplèstinè medikamentų prieinamumo programa: dabrafenibas bei BRAF ir MEK inhibitorių kombinacija (dabrafenibas su trametinibu).
\end{abstract}

\section{Ivadas}

Melanoma - piktybinis odos navikas, kilęs iš melanocitų, melaniną produkuojančių ląstelių. Dažniausiai melanoma išsivysto odoje, bet gali atsirasti ir kituose organuose, kurių ląstelès turi melanino, pvz.: gleivinių epitelyje (anogenitalinejje, orofaringinejje srityse, prienosiniuose ančiuose, akių junginejje, tinklainèje), smegenų dangaluose. Piktybinè melanoma yra heterogeninè liga, turinti keletą skirtingų biologinių subtipų: paviršiumi plintanti melano- ma, lentigo maligna melanoma, akrolentiginè melanoma, mazginè melanoma ir kiti. Kiekvienas skirtingas melanomos tipas turi skirtingą naviko išsivystymo kelią ir etiologinius veiksnius. Tiksli melanomos klasifikacija, naviko biologijos ir genomo suvokimas yra raktas i ligos mechanizmu pagrịstą gydymą (1).

Melanomos vystymąsi visu pirma paskatina išoriniai aplinkos veiksniai, įskaitant UV (ultravioletinius spindulius), kurie sukelia genetinius / epigenetinius melanocitu genų pokyčius. Piktybinès melanomos vystymesi labiausiai žinomi du pagrindiniai RAS/RAF/MEK/ERK (MAPK) ir PI3K/PTEN/AKT (AKT) signalo perdavimo keliai, kurie nenutrūkstamai aktyvuojami įvykus ląstelių genetiniams pokyčiams. Dél to sutrinka normali ląstelių proliferacija, diferenciacija, angiogenezé, vystosi melanoma. Siekiant surasti geriausią melanomos gydymo būdą, būtina suprasti melanomos biologiją, signalo perdavimo mechanizmus (5).

Ankstyvoje ligos stadijoje melanoma sẻkmingai gydoma chirurginiu būdu, tačiau kai liga metastazuoja reikalingas sisteminis gydymas, kuris iki $2011 \mathrm{~m}$. buvo beveik neefektyvus. Melanomos gydymo revoliucijos pradžia įvyko 2002 m. kuomet Davies ir kiti (2) nustatè aktyvuojančią B-raf protoonkogeno mutaciją, kuri būna $60 \%-70 \%$ melanomos atvejų. Vèliau atrastos ir c-KIT, RAS, RAF, c-RET genų mutacijos, kurių reikšmė melanomai išsivystyti bei gydyti aktyviai tiriama. BRAF genas koduoja serino/treonino kinazę, priklausančią RAS/RAF/MEK/ERK/MAPK signalo perdavimo keliui ląstelès viduje (3).

MAPK (mutageno aktyvuota proteinkinazė) kelią aktyvuoja mažas $\mathrm{G}$ baltymas RAS, esantis ląstelès plazminèje membranoje. Jis signalą perduoda ị ląstelès vidų aktyvuodamas RAF (BRAF), po to MEK ir ERK molekules ir galiausiai signalas perduodamas DNR nukleotidų transkripcijos mechanizmui (4).

Aktyvuojančios BRAF geno mutacijos ir intraląstelinių signalo kelių, reguliuojančių ląstelès augimo, dauginimosi, mirties mechanizmus, atradimas pakeitè melanomos biolo- 
gijos suvokimą ir atvėre plačias galimybes ieškoti taikinių teapijos prieš BRAF bei kitus onkogenus.

Vemurafenibas pirmas peroralinis selektyvus BRAF inhibitorius, patvirtintas nerezektabiliai ir metastazinei melanomai gydyti, esant BRAFV600E mutacijai. Jis inhibuoja nuolatinę RAF aktyvaciją esant mutuotam BRAF genui MAPK signalo perdavimo kelyje, tokiu būdu sutrinka signalo perdavimas ir ląstelès nebeskatinamos nekontroliuojamai daugintis (11). Vemurafenibas veiksmingas tik pacientams su BRAF geno mutacija, o esant melanomai su nemutuotu BRAF genu gali viekti priešingai ir aktyvuoti MAPK kelią (6). 3 fazès klinikinis tyrimas, kuriame vemurafenibas lyginant su dakarbazinu metastazinès, BRAF mutuotos, prieš tai negydytos melanomos gydymui pademonstravo reikšmingą bendro išgyvenamumo ir laiko be ligos progresavimo pailgejimą (7). Atsako dažnis vemurafenibo grupeje buvo $48 \%$, o dakarbazino grupejje tik $5 \%$. Vidutinis išgyvenamumas vemurafenibo grupejje pasiektas 13,2 mèn. Tuo tarpu dakarbazino grupejje tik 9,6 mèn. (HR$0,76,95 \%$ PI $=0,63-0,93)(8)$.

Dažniausi vemurafenibo nepageidaujami reiškiniai yra sąnarių skausmas, odos bèrimai, silpnumas, alopecija, fotosensibilizacija, pykinimas, viduriavimas. Odos plokščiu ląstelių karcinoma užfiksuota iki $26 \%$ atvejų (9).

Dabrafenibas antras selektyvus Braf inhibitorius, patvirtintas $2013 \mathrm{~m}$. JAV maisto ir vaistų administracijos ir 2014 m. Europos vaistų agentūros. 3 fazès klinikiniame tyrime dabrafenibas statistiškai reikšmingai pagerino vidutinị išgyvenamumą be ligos iki 5,1 mẻn., o vidutinị bendrą išgyvenamumą iki 18,2 mèn. lyginant su dakarbazinu, kur vidutinis išgyvenamumas be ligos 2,7 mèn., ir vidutinis bendras išgyvenamumas 15,6 mèn. gydant nerezektabilią ar metastazinę melanomą pacientams su BRAFV600 mutacija. Objektyvus atsako dažnis dabrafenibo grupejje buvo $50 \%$, o dakarbazino tik 3\% (10).

Dažniausi dabrafenibo nepageidaujami reiškiniai buvo odos (hiperkeratozè, papilomos, delnų- padų eritrodisestezija), nuovargis, galvos, sąnarių skausmas. Plokščių ląstelių odos karcinoma stebèta tik $6 \%$ pacientų, karščiavimas iki $8 \%(10)$.

Ivertinus galutinius klinikinių tyrimu rezultatus pastebèta, kad Braf inhibitoriai sukelia didelị atsako dažnị, tačiau šis atsakas dažnai trumpalaikis dèl išsivystančio rezistentiškumo maždaug po 5-7 mèn. gydymo $(13,15,16)$. Dèl šios priežasties pradèta ieškoti kaip užblokuoti ir kitas MAPK kelio grandis.

Trametinibas peroralinis selektyvus MEK1 ir MEK2 inhibitorius (12). Tirtas 3 fazès klinikiniame tyrime metastazinei melanomai gydyti, pacientams su BRAFV600E ar V600K mutacija. Vidutinị išgyvenamumą be ligos pailgino iki 4,8 mèn. lyginant su 1,5 mèn. chemoterapijos grupejje. Atsako dažnis trametinibo grupejje siekè $22 \%$, o chemoterapijos grupejje tik $8 \%$. Dažniausios nepageidaujamos reakcijos trametinibo grupeje buvo odos berimas, viduriavimas, periferinès edemos. Iki 7\% atvejų stebėta širdies kairiojo skilvelio išmetimo frakcijos sumažèjimas. Nestebèta nei vieno odos plokščiu ląstelių karcinomos atvejo (14).

Kai kuriuos Braf inhibicijos rezistentiškumo mechanizmus bandoma apeiti prie Braf inhibitoriaus melanomos gydymui pridejus MEK ar ERK inhibitorių. Dabrafenibo ir trametinibo kombinacija parode $15 \%$ naviko atsako dažnị pacientams, kuriems išsivystė rezistentiškumas gydant vemurafenibu (17), o prieš tai negydytiems pacientams su BRAF geno mutacija atsako dažnis $76 \%$. Be to, kombinacinis gydymas pailgino vidutinị išgyvenamumą be ligos progresavimo iki 9,4 mèn. lyginant su monoterapija dabrafenibu ( 5,8 mèn.) (19). Net ir nepageidaujamų reakcijų, tokių kaip odos plokščių ląstelių karcinoma, kombinacinio gydymo grupejje stebèta mažiau, tik 7\%, lyginant su dabrafenibo grupe (19\%).

Klaipėdos universitetinejje ligoninèje 2012-2014 m. pacientai, sergantys metastazavusia melanoma, buvo gydyti BRAF inhibitoriu vemurafenibu, o nuo $2013 \mathrm{~m}$. vykdyta išplèstinè medikamentu prieinamumo programa: dabrafenibas bei BRAF ir MEK inhibitorių kombinacija (dabrafenibas su trametinibu).

Analizės tikslas: ịvertinti BRAF inhibitoriu bei BRAF ir MEK inhibitorių kombinacijos saugumą, nepageidaujamus reiškinius gydant išplitusią ir metastazavusią melanomą su BRAFV600 mutacija, remiantis vieno centro patirtimi.

\section{Pacientai ir metodai}

Analizuotos 2 grupès pacientu, sergančių išplitusia ir metastazavusia odos melanoma. Visiems pacientams buvo nustatyta BRAFV600 mutacija. Vieni pacientai dèl metastazinès ligos anksčiau jau buvo gavę sistemini gydymą (chemoterapiją, imunoterapiją), kiti negavę jokio gydymo. Visų tirtų pacientų bendra būklè pagal ECOG (Eastern Cooperative Oncology Group) 0-2 balai. Iš viso analizuota 18 pacientu. 9 pacientams taikytas gydymas BRAF inhibitoriais, iš jų 5 vyrai ir 4 moterys, vidutinis jų amžius 55,7 metai. Kitai pacientu grupei ( 9pacientai) skirtas gydymas BRAF ir MEK inhibitorių kombinacija, iš jų 5 moterys ir 4 vyrai, vidutinis jų amžius 56 metai. Analizuotos visos nepageidaujamos reakcijos pasireiškusios gydymo BRAF ir BRAF bei MEK inhibitoriais gydymo metu. Nepageidaujami reiškiniai klasifikuoti pagal sunkumą remiantis CTC (Common Terminology Criteria) nepageidaujamų reiškinių kriterijais versija 4.0. Pagal šiuos kriterijus nepageidaujami 
reiškiniai skirstomi ị lengvus $\left(\mathrm{I}^{0}\right)$, vidutinio sunkumo $\left(\mathrm{II}^{0}\right)$, sunkius $\left(\mathrm{III}^{0}\right)$ ir labai sunkius, gyvybei pavojingus $\left(\mathrm{IV}^{0}\right)$.

\section{Rezultatai}

Visiems abiejose grupèse gydytiems pacientas stebèti ịvairaus laipsnio nepageidaujami reiškiniai (1 lentelè). Daugiausia pasireiškè $\mathrm{I}^{0}-\mathrm{II}^{0}$ toksiškumas, nestebeta nei vieno $\mathrm{IV}^{0}$ toksiškumo atvejo. Dèl nepageidaujamų reiškinių gydymas laikinai sustabdytas 6 pacientams, iš jų 3 BRAF inhibitoriu grupeje ir $3 \mathrm{BRAF} / \mathrm{MEK}$ inhibitorių kombinacijos grupeje. Gydymas dèl nepageidaujamų reiškinių nutrauktas tik 1 pacientui BRAF inhibitorių grupeje. Daugiausia abiejose grupèse stebèta odos toksinių reakcijų. Dažniausios gydytų BRAF inhibitoriais grupeje buvo kserozė $(33,3 \%)$, fototoksinè odos reakcija $(33,3 \%)$, odos eritema $(33,3 \%)$, keratomos $(33,3 \%)$, karpos $(33,3 \%)$, papilomos $(33,3 \%)$. Iš jų tik kserozès ir fototoksinè reakcijos III $^{0}$. BRAF ir MEK inhibitorių kombinacinio gydymo grupejje nepageidaujamų reiškinių buvo daug mažiau nei pirmojoje grupeje, iš jų taip pat dažniausiai pasireiškẻ odos toksinès reakcijos, tokios kaip odos eritema $(22,2 \%)$, kserozè $(11,1 \%)$, papulovezikulinis bèrimas $(11,1 \%)$, mazginè

1 lentelè. Abiejose tiriamujjų grupèse stebèti nepageidaujami reiškiniai

KS IF- kairiojo skilvelio išmetimo frakcija

\begin{tabular}{|c|c|c|c|c|}
\hline \multirow[t]{2}{*}{ Nepag. Reiškinys } & \multicolumn{2}{|c|}{$\begin{array}{c}\text { BRAF } \\
\text { inhibitoriai }\end{array}$} & \multicolumn{2}{|c|}{$\begin{array}{l}\text { BRAF } \\
\text { ir MEK } \\
\text { inhibitorių } \\
\text { kombinacija }\end{array}$} \\
\hline & $\mathbf{I}^{\mathbf{0}} \mathbf{I I}^{\mathbf{0}}$ & III $^{0}$ & $\mathbf{I}^{0}-\mathbf{I I}^{0}$ & III $^{0}$ \\
\hline Pireksija & 2 & 0 & 2 & 0 \\
\hline Bendr. silpnumas & 3 & 0 & 1 & 0 \\
\hline Kserozè & 3 & 1 & 1 & 0 \\
\hline Fototoksinè odos r-ja & 3 & 1 & 0 & 0 \\
\hline Papulovezikulinis bėrimas & 2 & 0 & 1 & 0 \\
\hline Odos eritema & 3 & 0 & 2 & 0 \\
\hline Odos keratoma & 3 & 0 & 0 & 0 \\
\hline Odos karpos & 3 & 0 & 0 & 0 \\
\hline Mazginè eritema & 1 & 0 & 1 & 0 \\
\hline Odos niežulys & 1 & 0 & 0 & 0 \\
\hline Folikulinė keratozė & 1 & 0 & 0 & 0 \\
\hline Odos pleiskanojimas & 2 & 0 & 0 & 0 \\
\hline Papiloma & 3 & 0 & 2 & 0 \\
\hline Odos skausmas & 1 & 0 & 0 & 0 \\
\hline Uveitas & 0 & 1 & 0 & 0 \\
\hline Rinitas & 1 & 0 & 0 & 0 \\
\hline Artralgija & 1 & 0 & 1 & 0 \\
\hline KS IF sumažèjimas & 0 & 0 & 1 & 1 \\
\hline Neutropenija & 0 & 0 & 1 & 0 \\
\hline
\end{tabular}

eritema $(11,1 \%)$. Tai pat abiejose tiriamujų grupėse stebėta pireksija ir artralgija. Skirtingai nuo gydytų BRAF inhibitoriais grupès, BRAF ir MEK inhibitoriu grupeje stebètas kairiojo skilvelio (KS) išmetimo frakcijos (IF) sumažejimas $>20 \%$, kas labiau būdinga MEK inhibitoriams bei 1 atvejis $\mathrm{II}^{0}$ neutropenijos. BRAF inhibitoriu grupeje pasireiškè gleiviniu uždegimas (uveitas, rinitas), ko nebuvo stebèta BRAF ir MEK inhibitoriu grupeje. Abiejose tiriamosiose grupèse nestebèta nei vieno odos plokščių ląstelių karcinomos atvejo (1 letelè).

\section{Išvados}

Dažniausi nepageidaujami reiškiniai gydant BRAF inhibitoriais bei BRAF ir MEK inhibitoriu kombinacija yra odos toksinès reakcijos. Daugiausia stebetos nedidelio ir vidutinio laipsnio nepageidaujamos reakcijos, sunkių, gyvybei pavojingų pašalinių nepageidaujamų reiškinių nebuvo. BRAF inhibitorių grupeje nepageidaujamų reakcijų pastebèta daugiau nei BRAF ir MEK inhibitoriu kombinacijos grupeje. Metastazavusios melanomos gydymas BRAF inhibitoriais ir BRAF bei MEK inhibitorių kombinacija yra saugus, visos pašalinès reakcijos, taikant profilaktinị ir ankstyvą gydymą yra gerai kontroliuojamos ir toleruojamos.

\section{Literatūra}

1. Whiteman DC, Pavan WJ, Bastian BC.The melanomas: a synthesis of epidemiological, clinical, histopathological, genetic, and biological aspects, supporting distinct subtypes, causal pathways, and cells of origin. Pigment Cell Melanoma Res 2011;24(5):879-897.

2. Davies H, Bignell GR, Cox C. et al. Mutations of the BRAF gene in human cancer. Nature 2002;417:949-954.

3. Brose MS, Volpe P, Feldman M et al. BRAF and RAS mutations in human lung cancer and melanoma. Cancer Res 2002;62:6997-7000.

4. V. Gray-Schopfer, C. Wellbrock, and R. Marais Melanoma biology and new targeted therapy. Nature 2007; 445(7130): 851-857.

5. Ichiro Yajima, Mayuko Y. Kumasaka et al. RAS/RAF/MEK/ ERK and PI3K/PTEN/AKT Signaling in Malignant Melanoma Progression and Therapy. Dermatology Research and Practice. 2012; Article ID 354191.

6. Oseph, EW. et al. The RAF inhibitor PLX4032 inhibits ERK signaling and tumor cell proliferation in a V600E BRAFselective manner. Proc. Natl. Acad. Sci. U.S.A. 2010; 107: 14903-14908.

7. Chapman, PB. et al. BRIM-3 Study Group. Improved survival with vemurafenib in melanoma with BRAF V600E mutation. N. Engl. J. Med 2011; 364: 2507-2516.

8. Chapman, PB. et al. Updated overall survival results for 
BRIM-3, a phase III randomized, open-label, multicenter trial comparing BRAF inhibitor vemurafenib with dacarbazine in previously untreated patients with BRAF V600E-mutated melanoma. 2012. J. Clin. Oncol. 30.

9. Su F. et al. RAS mutations in cutaneous squamous-cell carcinomas in patients treated with BRAF inhibitors. N. Engl. J. Med 2012; 366: 207-215.

10. Hauschild A. et al. An update on BREAK-3, a phase III, randomized trial: Dabrafenib (DAB) versus dacarbazine (DTIC) in patients with BRAF V600E-positive mutation metastatic melanoma (MM) [abstr.]. J. Clin. Oncol 2013; 31: 9010.

11. Bollag G, Hirth P, Tsai J. et al. Clinical efficacy of RAF inhibitor needs broad target blockade in BRAF-mutant melanoma. Nature 2010; 467:596-9.

12. Gilmartin AG. et al. GSK1120212 (JTP-74057) is an inhibitor of MEK activity and activation with favorable pharmacokinetic properties for sustained in vivo pathway inhibition. Clin. Cancer Res. 2011; 17: 989-1000.

13. Poulikos I. et al. RAF inhibitor resistance is mediated by dimerization of aberrantly spliced BRAF(V600E). Nature 2011; 480:387-390.

14. Flaherty KT. et al. METRIC Study Group. Improved survival with MEK inhibition in BRAF-mutated melanoma. N. Engl. J. Med 2012; 367: 107-114.

15. Shi H. et al. Melanoma whole-exome sequencing identifies (V600E)B-RAF amplification-mediated acquired B-RAF inhibitor resistance. Nat. Commun 2012; 3: 724.

16. Johannessen CM. et al. COT drives resistance to RAF inhibition through MAP kinase pathway reactivation. Nature 2010; 468: 968-972.

17. Infante R. et al. Phase I/II study to assess safety, pharmacokinetics, and efficacy of the oral MEK 1/2 inhibitor GSK1120212 (GSK212) dosed in combination with the oral BRAF inhibitor GSK2118436 (GSK436) [abstr.]. 2011. J. Clin. Oncol. 29.
18. Flaherty KT. et al. Combined BRAF and MEK inhibition in melanoma with BRAF V600 mutations. N. Engl. J. Med 2012; 367: 1694-1703.

\section{ANTI BRAF THERAPY FOR PATIENTS WITH METASTATIC MELANOMA. ADVERSE EVENTES}

\author{
A. Česas, A. Poškienè, J. Česienė
}

Key words: melanoma, BRAF gene mutation, BRAF and MEK inhibitor, adverse event.

Summary

Melanoma is malignant skin cancer originated from melanin producing cells. Melanomagenesis is initially triggered by environmental agents including ultraviolet (UV), which induces genetic/epigenetic alterations in the chromosomes of melanocytes. In human melanomas, the RAS/RAF/MEK/ERK (MAPK) and the PI3K/PTEN/AKT (AKT) signaling pathways are two major signaling pathways and are constitutively activated through genetic alterations. In 2002 Davies et al. discovered activating BRAF mutation, witch is found in $60-70 \%$ cases of melanoma, and new era of BRAF inhibition in melanoma targeting terapy started.

From 2012 in Klaipeda university hospital we treated 18 pacients with BRAF mutated malignant melanoma with BRAF inhibitors and combination of BRAF and MEK inhibitors. We analised safety and adverse events (AE) of BRAF inhibitors and combination BRAF/ MEK inhibitors. The most common AE was skin toxicity and mostly observed CTC grade 1-2. No grade 4 toxicity. In patients group treated with BRAF inhibitors monotherapy AE's were observed more often then in patients treated with BRAF/MEK inhibitors combination. Though treatment with BRAF and BRAF/MEK inhibitors is well tolerated and safe.

Correspondence to: a.cesas@kul.lt

Gauta 2014-09-24 